\title{
Hydrologic Setting Dictates the Sensitivity of Ecosystem Metabolism to Climate Variability in Lakes
}

\author{
Isabella A. Oleksy, ${ }^{1 *} \odot$ Stuart E. Jones, ${ }^{2}$ and Christopher T. Solomon ${ }^{1}$
}

${ }^{1}$ Cary Institute of Ecosystem Studies, Millbrook, New York, USA; ${ }^{2}$ Dept. of Biological Sciences, University of Notre Dame, Notre Dame, Indiana, USA

\begin{abstract}
Global change is influencing production and respiration in ecosystems across the globe. Lakes in particular are changing in response to climatic variability and cultural eutrophication, resulting in changes in ecosystem metabolism. Although the primary drivers of production and respiration such as the availability of nutrients, light, and carbon are well known, heterogeneity in hydrologic setting (for example, hydrological connectivity, morphometry, and residence) across and within regions may lead to highly variable responses to the same drivers of change, complicating our efforts to predict these responses. We explored how differences in hydrologic setting among lakes influenced spatial and inter annual variability in ecosystem metabolism, using high-frequency oxygen sensor data from 11 lakes over 8 years. Trends in mean metabolic rates of lakes generally followed gradients of nutrient and carbon concentrations, which were lowest in seepage lakes, followed by drainage lakes, and higher in bog lakes.
\end{abstract}

Received 26 January 2021; accepted 29 September 2021; published online 29 October 2021

Supplementary Information: The online version contains supplementary material available at https://doi.org/10.1007/s10021-021-0071 8-5.

Author Contributions IAO, SEJ, CTS conceived the study design and research questions; IAO analyzed the data; IAO, SEJ, and CTS wrote the manuscript.

*Corresponding author; e-mail: bellaoleksy@gmail.com
We found that while ecosystem respiration (ER) was consistently higher in wet years in all hydrologic settings, gross primary production (GPP) only increased in tandem in drainage lakes. However, interannual rates of ER and GPP were relatively stable in drainage lakes, in contrast to seepage and bog lakes which had coefficients of variation in metabolism between $22-32 \%$. We explored how the geospatial context of lakes, including hydrologic residence time, watershed area to lake area, and landscape position influenced the sensitivity of individual lake responses to climatic variation. We propose a conceptual framework to help steer future investigations of how hydrologic setting mediates the response of metabolism to climatic variability.

Key words: Hydrologic connectivity; Drainage ratio; Residence time; Lake metabolism; Net ecosystem production; Landscape position; Stability; Annual precipitation; Water retention time.

\section{HighLIGHTS}

- Residence time determines the sensitivity of metabolism to precipitation.

- Variability in gross primary production depends on hydrologic setting.

- Ecosystem respiration is consistently higher in wet years. 


\section{INTRODUCTION}

The balance between carbon (C) fixation and mineralization in Earth's ecosystems is changing in response to global environmental change (Melillo and others 1990). These metabolic processes control biogeochemical cycling and system productivity and integrate multiple scales of organization from microbes to ecosystems (West and others 1997). Despite occupying a small percentage of Earth's surface area, inland waters play a disproportionately large role in the global biogeochemical cycling (Tranvik and others 2009; Cheng and Basu 2017; Drake and others 2018). Understanding the role that inland waters play in transforming and assimilating $\mathrm{C}$ and nutrients as they move through the freshwater continuum is critical. However, predicting variability in aquatic ecosystem function is notoriously difficult, in part because lakes integrate signals of terrestrial processes and their metabolism is sensitive to regional and global climatic change (Adrian and others 2009; Jackson and others 2016).

Climate, and in particular temperature and precipitation, influences spatial variability in ecosystem metabolism regimes in terrestrial and aquatic biomes across the globe (Whittaker 1962; Bernhardt and others 2018; Dodds and others 2019). Interannual variability in precipitation affects the water quality of lakes, though the magnitude of the effect varies across a landscape (Collins and others 2019; Oleksy and others 2020). Thus, altered precipitation patterns are one facet of global environmental change that will have profound implications for ecosystem metabolism. Many areas in the Northern Hemisphere are already experiencing increases in total annual precipitation, frequency of extreme precipitation events, and duration of droughts (Groisman and others 2012), and climate change models predict an intensification of hydrologic cycles globally (Held and Soden 2006; Wentz and others 2007). Interannual variability in precipitation can lead to large swings in terrestrial production (Fay and others 2011; Hsu and others 2012), but our understanding of how sensitive aquatic ecosystem metabolism is to this variation is limited and primarily focused on pulse disturbances (for example, hurricanes and storms; Klug and others 2012; Vachon and Del Giorgio 2014; Zwart and others 2017).

Interannual variation in precipitation can alter ecosystem metabolism in lakes via two distinct but interrelated pathways: delivery of solutes and delivery of water (Figure 1). In simple terms, more precipitation means that more solutes and more water are delivered to the lake (Schiff and others 1998). Solutes, particularly nutrients and dissolved organic matter, can fuel primary production and respiration (Laas and others 2012; Wilkinson and others 2013; Richardson and others 2016), but delivery of water may limit the potential for these reactions by shortening the residence time of solutes in the lake or by diluting the concentration at which solutes are delivered (Hotchkiss and others 2018). Lake hydrologic residence time (HRT) is key constraint on biogeochemical cycling rates (Vachon and others 2017a; Jones and others 2018), including primary production (Giorgio and Peters 1994; Howarth and others 2000; Hosen and others 2019).

Previous work suggests that responses to variation in precipitation will likely differ from lake to lake because of features of the lake and its watershed that influence loads of solutes and water (Figure 1A). We refer to this set of features as a lake's hydrologic setting, which we conceptualize in terms of a few simple features of the landscape. The size of the watershed relative to the size and depth of the lake (WA:LA) determines how quickly hydrologic inflows move through the lake, and in combination with watershed land cover controls solute delivery to the lake. The landscape position of the lake in the hydrologic network determines the extent to which decreases in precipitation and surface water runoff may be buffered by groundwater inputs. Finally, the importance of evaporation in the water budget determines the extent to which the residence time of solutes may be disconnected from that of water, and the potential for evapoconcentration of solutes during dry periods (Zwart and others 2018). Ultimately, hydrologic setting emerges from the interaction between lake morphometry, lake watershed characteristics, and climate, all of which work together to influence temporal variation in loads of water and solutes, and ultimately give rise to variation in biogeochemical processes.

Three lake archetypes, with distinct hydrologic settings, are common in many formerly glaciated lake regions around the globe (Wetzel 2001; Figure 1B). We describe these in the context of the region that we studied here, but many aspects of our description are applicable in other regions as well. Seepage lakes receive relatively limited inputs of solutes because they occupy small watersheds relative to their lake area. Drainage lakes occupy large watersheds relative to their lake area, have surface inflows and outflows, and are well connected to groundwater. Bog lakes are intermediate between seepage and drainage lakes. Their WA:LA is higher than seepage lakes, overlapping with the 


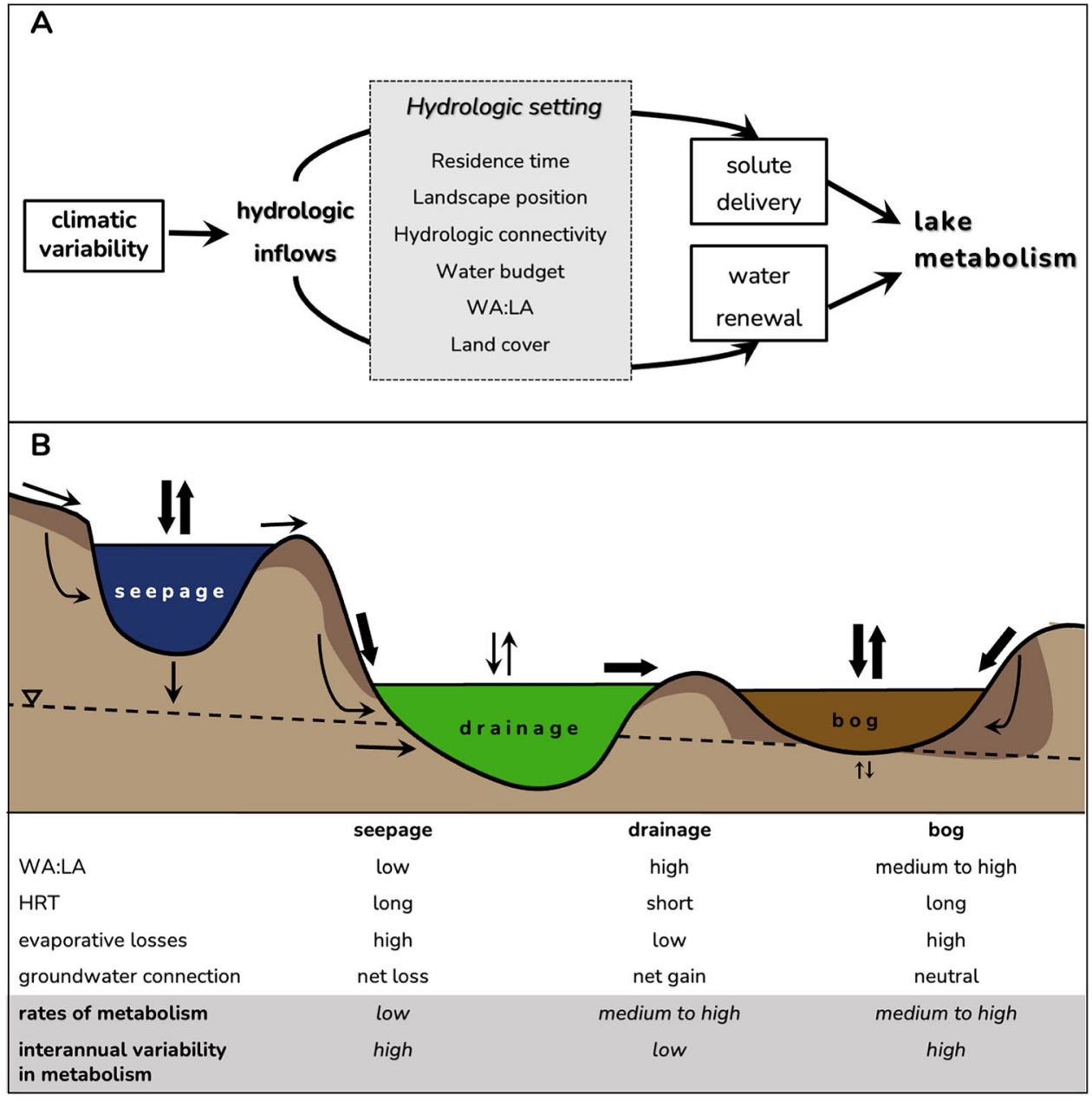

Figure 1. A A conceptual diagram illustrating the relationship between climate variability (distal control), hydrologic setting (landscape filter), and lake metabolism (response). Climatic variability (for example, precipitation) exerts control over hydrologic inflows which, in turn, influence lake metabolism via solute delivery and water renewal. In lake nutrient availability and hydrologic residence time ultimately interact to give rise to spatial and temporal variability in lake metabolism. B A cartoon landscape illustrating how three common lake archetypes (seepage, drainage, and bog lakes) vary in their hydrologic setting. The size and direction of the arrows indicate the importance of various hydrologic gains and losses to the overall water budget (surface inflows and outflows, direct precipitation, evaporation, groundwater). The table describes the aspects of landscape position and hydrology of the three lake archetypes, specifically the watershed area to lake area (WA:LA), hydrologic residence time, and evaporative losses. In gray we highlight the predicted spatial variability in lake ecosystem metabolism rates and interannual variability in those rates based on established relationships between landscape position and water chemistry.

low end of the WA:LA continuum for drainage lakes. Their watersheds are dominated by wetlands with high areal solute yields, which combined with relatively large WA:LA means that solute inputs are high. They receive little, if any, groundwater input and typically do not have surface outlets, thus residence times are long and evaporation is an important component of the water budget (Hanson and others 2018; Zwart and others 2018).

In this study, our goal was to assess how hydrologic setting influences lake metabolism responses to a common climatic driver. Overall, we expected that hydrologic setting would provide a template for the baseline biogeochemical conditions and would thus structure spatial variability in lake metabolism as demonstrated in other landscape metabolism studies (Hanson and others 2003; Solomon and others 2013; Bogard and others 2020). Because increased precipitation generally results in higher in-lake nutrient concentrations and dissolved organic matter concentrations (Schiff and others 1998), we expected that wetter years would be associated with higher rates of ecosystem metabolism in all lakes, and that the concomitant 
high allochthonous inputs would result in ER outpacing GPP (Laas and others 2012; Wilkinson and others 2013; Richardson and others 2016). We further hypothesized that the magnitude of interannual variability in metabolism would be modified by the hydrologic setting based on the established relationships between landscape position and water chemistry, described above (Figure $1 \mathrm{~B})$. To that end, we quantified the patterns in ecosystem metabolism within and across lakes of contrasting hydrologic setting, asking how interannual variation in metabolism is related to variation in precipitation. Finally, we explored what we can learn from these relationships about the underlying mechanisms at work.

Specifically, in the case of seepage lakes, we hypothesized that interannual variation in ecosystem metabolism would exceed that of lakes lower in the landscape. Our rationale is that the water budgets of these lakes are not buffered from dry conditions by groundwater inputs because they are perched above the regional groundwater table; consequently, they may experience substantial groundwater losses in dry years (Kratz and others 1991; McCullough and others 2019) and greater interannual variability in nutrient concentrations necessary for fueling ecosystem metabolism (Webster and others 1996). In contrast, in drainage lakes, we expected relatively little interannual variability in metabolism in response to precipitation because these lakes receive high solute loads, have short residence times, and have dampened variability in solute concentrations due to hydrologic attenuation (Kratz and others 1991, 1997; Lottig and others 2013). The increased delivery of water in wet years may limit the potential for these reactions in lakes with shorter residence times (Zwart and others 2017; Hotchkiss and others 2018). We hypothesized that interannual variability in metabolism of bog lakes would be higher than drainage lakes because these systems receive similarly high nutrient inputs but have more time to process those inputs due to longer HRT. Bog lakes are additionally connected to a nutrient-rich bog mat which may provide important DOM-associated nitrogen $(\mathrm{N})$ and phosphorus $(\mathrm{P})$ subsidies that may stimulate both phototrophs and heterotrophs (Kissman and others 2017). In these humic lakes, we expected GPP to be more temporally variable than ER because of the greater potential for light limitation of phototrophs when terrestrial loads are relatively high (Kelly and others 2018).

\section{Methods}

We studied 11 lakes representing three hydrologic setting archetypes (seepage, drainage, and bog). We conducted a series of analyses to explore how the hydrologic setting of these 11 lakes influenced the response of ecosystem metabolism to variation in annual precipitation over the span of eight years. All of the lakes are located within a few kilometers of each other and are thus subjected to the same climatic drivers and weather. First, we tested whether lakes in our study represented distinct types based on hydrology, land cover, and morphometry. Second, we used bi-weekly measurements of water chemistry to ask whether solute concentrations differed among the lake types and how variable those concentrations were through space and time. Third, we used high-frequency measurements of dissolved oxygen to estimate ecosystem metabolism and investigated interannual variation in metabolism by lake type. Finally, we assessed the role of hydrologic setting in modifying sensitivity of metabolism to variability in precipitation. We contrast responses by treating hydrologic setting as a categorical variable (seepage, drainage, or bog lake). We also consider continuous gradients of WA:LA and HRT, which we hypothesize are the two most important components of hydrologic setting that determine both the magnitude of inputs and degree to which biogeochemical processing can occur within the system (Figure 1).

\section{Site Description and Data Collection}

The study lakes are located at the University of Notre Dame Environmental Research Center (UNDERC), within the Northern Highlands Lake District on the border of Michigan and Wisconsin in the upper Midwest, USA. This lake district includes thousands of lakes formed after the last glaciation (10,000-12,000 years before present), which left tens of meters of glacial till and sand outwash with low cation exchange capacity (Kitchell and Carpenter 1993). The region is a mosaic of secondgrowth temperate forests $(52 \%)$, peatlands $(28 \%)$, and open water $(13 \%)$ with low human population density (Peterson and others 2003). Our study lakes ranged from oligo-mesotrophic to dystrophic and spanned a range of hydrologic settings (Table 1).

For lakes larger than $3000 \mathrm{~m}^{2}$, lake areas were derived from polygons contained in the USGS National Hydrography Dataset (NHD; U.S. Geologic Survey 2020). For Northgate, which was smaller 
Table 1. Lake Characteristics Including Watershed Area (WA), Lake Surface Area (LA), Volume, Maximum Lake Depth $\left(z_{\max }\right)$, Drainage Ratio (WA:LA), Gross Primary Production (GPP), Ecosystem Respiration (ER), Total Phosphorus (TP), Chlorophyll a. (chl), Dissolved Organic Carbon (DOC), Absorbance at $440 \mathrm{~nm}\left(\mathrm{abs}_{440}\right)$, Total Nitrogen (TN), Light Attenuation Coefficient $\left(\mathrm{k}_{\mathrm{D}} ; \mathrm{m}^{-1}\right)$, Light Availability at the Bottom of the Mixed Layer $\left(I_{\mathrm{z}}\right)$

\begin{tabular}{|c|c|c|c|c|c|c|c|c|c|c|c|c|}
\hline Type & Lake & $\begin{array}{l}\text { WA } \\
\mathrm{km}^{2}\end{array}$ & $\begin{array}{c}\text { Elev } \\
\mathrm{m}\end{array}$ & $\begin{array}{l}\text { Vol } \\
\qquad 1000 \mathrm{~m}^{3}\end{array}$ & $\begin{array}{l}\text { HRT } \\
\text { days }\end{array}$ & $\begin{array}{l}\text { LA } \\
\text { ha }\end{array}$ & $\begin{array}{l}\text { in- } \\
\text { flows }\end{array}$ & $\begin{array}{l}\text { out- } \\
\text { flows }\end{array}$ & \multicolumn{2}{|c|}{$\begin{array}{l}\text { GPP } \\
\underset{\text { day }^{-1}}{\mathrm{mg} \mathrm{O}_{2} \mathrm{~L}^{-1}}\end{array}$} & \multicolumn{2}{|c|}{$\begin{array}{l}\text { ER } \\
\qquad \text { day }^{-1}\end{array}$} \\
\hline \multirow{4}{*}{ bog } & Bolger (BO) & 0.15 & 508 & 23 & 592 & 0.8 & 0 & 0 & \multicolumn{2}{|c|}{$1.9(0.6)$} & \multicolumn{2}{|c|}{$2.7(0.6)$} \\
\hline & (CB) & 0.17 & 510 & 50 & 1089 & 1.6 & 0 & 0 & \multicolumn{2}{|c|}{$0.8(0.3)$} & \multicolumn{2}{|c|}{$1.2(0.6)$} \\
\hline & $\begin{array}{l}\text { Hummingbird } \\
\quad(\mathrm{HB})\end{array}$ & 0.13 & 516 & 27 & 746 & 0.7 & 0 & 1 & \multicolumn{2}{|c|}{$1.3(0.6)$} & \multicolumn{2}{|c|}{$1.6(0.7)$} \\
\hline & North Gate (NG) & 0.04 & 514 & 8 & 1113 & 0.2 & 0 & 0 & \multicolumn{2}{|c|}{$0.3(0.1)$} & \multicolumn{2}{|c|}{$0.7(0.3)$} \\
\hline \multirow[t]{3}{*}{ drainage } & Brown & 4. & 504 & 79 & 38 & 28.6 & 1 & 1 & \multicolumn{2}{|c|}{$1.3(0.2)$} & \multicolumn{2}{|c|}{$1.6(0.3)$} \\
\hline & Mor & 1 . & 506 & 14 & 18 & 5.1 & 3 & 1 & \multicolumn{2}{|c|}{$1.4(0.2)$} & \multicolumn{2}{|c|}{$1.7(0.2)$} \\
\hline & Ward ( & 0.22 & 509 & 77 & 111 & 1.6 & 0 & 1 & \multicolumn{2}{|c|}{$0.8(0.2)$} & \multicolumn{2}{|c|}{$0.9(0.2)$} \\
\hline \multirow[t]{4}{*}{ seepage } & Bay (BA) & 2.37 & 516 & 2955 & 1256 & 68.2 & 1 & 1 & \multicolumn{2}{|c|}{$0.3(0.1)$} & \multicolumn{2}{|c|}{$0.2(0.1)$} \\
\hline & Cram & 0.61 & 511 & 1302 & 872 & 26.4 & 0 & 1 & \multicolumn{2}{|c|}{$0.3(0.1)$} & \multicolumn{2}{|c|}{$0.4(0.2)$} \\
\hline & $\mathrm{E}$ & .19 & 515 & 124 & $286^{*}$ & 3.2 & 0 & 1 & \multicolumn{2}{|c|}{$0.7(0.1)$} & \multicolumn{2}{|c|}{$1.0(0.3)$} \\
\hline & West & 0.1 & 515 & 194 & $706^{*}$ & 5 & 0 & 0 & \multicolumn{2}{|c|}{$0.6(0.1)$} & \multicolumn{2}{|c|}{$0.9(0.3)$} \\
\hline Type & Lake & $\stackrel{\mathrm{TN}}{\mu \mathrm{g} \mathrm{L}}$ & & $\begin{array}{l}\mathrm{TP} \\
\mu \mathrm{g} \mathrm{L}^{-1}\end{array}$ & $\begin{array}{l}\text { chl } \\
\mu \mathrm{g} \mathrm{L}^{-1}\end{array}$ & & $\begin{array}{l}C \\
g_{L^{-1}}\end{array}$ & $\begin{array}{r}\mathrm{abs}_{440} \\
\mathrm{~m}^{-1}\end{array}$ & $\begin{array}{c}Z_{\max } \\
m\end{array}$ & $\mathrm{k}_{\mathrm{D}} \mathrm{m}$ & & $\begin{array}{l}\mathrm{I}_{\mathrm{z}} \mu \mathrm{mol} \\
\text { photons } \\
\mathrm{m}^{-2} \mathrm{~s}^{-1}\end{array}$ \\
\hline \multirow[t]{4}{*}{ bog } & & \multicolumn{2}{|c|}{$1008(291)$} & $37.3(11.2)$ & 21.5 & \multicolumn{2}{|c|}{$22.7(2.6)$} & & 3.5 & \multicolumn{2}{|c|}{$9.6(0.9)$} & 211 \\
\hline & Cranberry (CB) & $673(2$ & & $16.5(8.5)$ & $7.5(3.2)$ & 21 & 1.9) & $0.6(0.1)$ & 7.9 & $9.2(\mathrm{C}$ & .6) & $74(4)$ \\
\hline & Humr & $848(1)-1$ & & $23.9(7.5)$ & $13.3(5.9)$ & 25.6 & (3.3) & $0.9(0.2)$ & 7.6 & 10.8 & 1.6) & $65(11)$ \\
\hline & North & 715( & & $13.5(4.6)$ & $7.9(6.5)$ & 28.8 & $(4)$ & $0.9(0.1)$ & ) 7.9 & & $.8)$ & $51(9)$ \\
\hline drainage & Browl & $755(4$ & & $26.7(10.4)$ & $14.7(6.5)$ & 11.9 & (3.9) & $0.2(0.1)$ & 4.9 & 5.3 & & $101(2$ \\
\hline & Morri & $727(1)$ & & $25.3(7.8)$ & $14.2(4.4)$ & 19.2 & $(2.6)$ & $0.4(0.1)$ & 6.7 & $8.2(1$ & & 77 (11) \\
\hline & Ward (WA) & $666(2)$ & & $13.4(4.9)$ & $5.5(2.6)$ & 13.8 & $(3.2)$ & $0.2(0.1)$ & 8.2 & $6(1.4$ & & $109(19$ \\
\hline seepage & Bay (BA) & $567(3)$ & & $12(4.1)$ & $4.3(0.8)$ & & (0.8) & 0.1 & 12.2 & & .4) & $137(1$ \\
\hline & Cramp & $439(7) r)$ & & $11.4(4.4)$ & $3.8(1.6)$ & & $(0.7)$ & 0.1 & 18.5 & 2.5 & .3) & $171(1$ \\
\hline & East Long (EL) & 489 & & $15.8(4.2)$ & $7.2(1.7)$ & 9.9 & (1.5) & $0.3(0.1)$ & ) 14 & 4.3 & $.6)$ & $136(1$ \\
\hline & West Long (WL) & $451(6$ & & $13.9(4.1)$ & $5.3(1.8)$ & 7.5 & $(0.8)$ & 0.1 & 14 & & .3) & $160(9)$ \\
\hline
\end{tabular}

Values are presented as summer means \pm standard deviation (June-August, inclusive) across all years. *HRT for all lakes except EL and WL were from (Hanson et al. 2018); estimates for EL and WL are from (Zwart 2017).

than $3000 \mathrm{~m}^{2}$, a polygon was created using an overlay of satellite imagery (Google Earth) and the USGS NHD shapefile (Zwart and others 2018). The east and west basins of Long Lake were experimentally separated using a chemically impermeable curtain for the entire extent of this study and therefore custom polygons were created for these basins as well. Watershed areas were delineated from $10 \mathrm{~m}$ resolution digital elevation model data provided in the National Elevation Dataset (Gesch and others 2018) using Whitebox Tools (Lindsay 2016; Wu 2020). Proportional land cover for watersheds was calculated from the 2016 National Land Cover Database (Homer and others 2020).
Each year (2012-2018), we collected weekly or bi-monthly water chemistry samples and temperature-dissolved oxygen profiles for each lake between mid-May and mid-August. We obtained integrated water column samples from the upper mixed layer, which we analyzed for total nitrogen (TN), total phosphorus (TP), dissolved organic carbon (DOC), absorbance at $440 \mathrm{~nm}\left(\mathrm{abs}_{440}\right)$, and chlorophyll $a(\operatorname{chl} a)$. We defined the upper mixed layer depth as the shallowest depth at which the vertical temperature gradient exceeded $1{ }^{\circ} \mathrm{C} \mathrm{m}^{-1}$. We measured photosynthetically active radiation (PAR) every $0.5 \mathrm{~m}$ from the surface to the depth at $1 \%$ of surface light and used this profile to deter- 
mine the light extinction coefficient $\left(\mathrm{k}_{\mathrm{D}}\right)$. We analyzed TN and TP using persulfate digestion and the spectrophotometric method (Olsen 2008, Menzel and Corwin 1965), chl a using methanol extraction and a fluorometer (Welschmeyer 1994), and DOC using a Shimadzu TOC-V total organic carbon analyzer (Shimadzu Scientific Instruments, Kyoto, Japan).

Between May and August each year we used automated sensors to measure dissolved oxygen at $0.5 \mathrm{~m}$ depth (miniDot optical DO sensor, Precision Measurement Engineering Inc., Vista, CA) and water temperature at 5-17 depths spanning the entire water column (Onset HOBO Pendants, Onset Computer Corporation) at 10-min intervals in each of the 11 lakes. We estimated gross primary production $(\mathrm{GPP})$, respiration (ER), and the difference between the two (net ecosystem production; NEP = GPP-ER), using the diel oxygen method (Odum 1956) as implemented by Solomon and others (2013). Mean wind speed, air temperature, and PAR from measurements on West and East Long lakes were used in estimating metabolism for all lakes (Onset HOBO met station, Onset Computer Corporation). All lake chemistry and sensor data are available online (Solomon and others 2018).

We used the prism $\mathrm{R}$ package to obtain estimates of precipitation for each lake from grid-type climate data estimations (Hart and Bell 2015; PRISM Climate Group 2020). We extracted year-round daily precipitation and calculated total antecedent precipitation (previous October-current August, inclusive; analogous to a water-year) for each year of our study. We excluded the month of September in our precipitation totals because our metabolism estimates extended only through the end of $\mathrm{Au}$ gust.

We obtained hydrologic residence time estimates from a calibrated surface-groundwater model developed for the Northern Highlands Lake District (Hanson and others 2018). We calculated HRT as the lake volume divided by the sum of evaporation, groundwater, and surface water losses. We set surface water outflow values to zero for a few lakes which we know have no surface water outflows (CB, BO, NG). Two lakes (EL and WL) have no modeled HRT estimates because the lake was experimentally separated by a curtain in 2012 (Zwart and others 2016) and instead use estimates of HRT from Zwart (2017).

\section{Statistical Analysis}

All statistical analyses were performed in $\mathrm{R}$ version 3.6.1 (R Core Team 2019). To confirm that the lakes in our study represented distinct types in terms of hydrologic setting we ran principal component analyses with the FactoMineR package (Lê and others 2008). We included key descriptors of hydrologic setting including watershed area, HRT, lake morphometry (volume, surface area, maximum depth), land cover, and WA:LA. To examine the multivariate differences by lake type, we performed permutational multivariate analysis of variance (perMANOVA) with Euclidean distances among lakes and 999 permutations using the adonis function in the vegan package (Anderson 2001; Oksanen and others 2019).

Next, we asked whether mean solute concentrations differed among the lake types and how variable those concentrations were between years in each lake type. We calculated summer means (June-August) for each solute and each lake. Because $\mathrm{C}, \mathrm{N}$, and $\mathrm{P}$ concentrations in these lakes were highly collinear, we used PCA to visualize temporal variability and lake-type groupings in scaled water chemistry data across the 11 lakes. We performed perMANOVA analyses to test for multivariate differences in water chemistry by lake type, as described above. We then used the Mantel test in the vegan package to test for multivariate correlation between hydrologic setting and chemistry (Oksanen and others 2019).

Lastly, we asked whether interannual variability in pelagic metabolism was related to variation in annual precipitation and if so, how variation in metabolism differed by lake type. We calculated the summer mean (June-August, inclusive) of all nutrient measurements and daily metabolism estimates. For comparison across sites, metabolism (GPP, ER, NEP) and water chemistry (DOC, TP, TN, $\left.a s_{440}\right)$ variables were scaled (z-transformed) prior to running correlations with precipitation metrics. For each summer mean parameter $X$ in lake $i$, the $\mathrm{Z}$-score was calculated as $\left(\mathrm{X}_{i}-\operatorname{mean}(\mathrm{X})\right) / \mathrm{st}$. $\operatorname{dev}(\mathrm{X})$, where the mean and standard deviation were calculated for parameter values across the annual mean in lake $i$. To assess interannual variability in metabolism in each lake and lake type, we calculated the coefficient of variation (c.v.) in metabolism responses for each lake as the standard deviation across all years divided by the mean across all years, which we then compared against variables describing hydrologic setting (WA:LA, hydrologic residence time). We used a one-way analysis of variance (ANOVA) to test for differences in the c.v. of GPP and ER by hydrologic setting and performed pairwise comparisons among lake types. 


\section{Results}

Seepage, drainage, and bog lakes varied in their hydrologic setting, particularly along gradients of landscape position, lake morphometry, and watershed land cover (perMANOVA $\mathrm{F}_{2,10}=2.6695$, $p<0.001$; Figure 2A). In the set of lakes we considered, seepage lakes have small watersheds and are at a higher elevation in the landscape, while drainage lakes have large watersheds dominated by deciduous forest and are positioned at a lower elevation in the landscape; bog lakes are somewhat intermediate, have high proportions of wetlands in their watersheds, and are also positioned relatively low in the landscape. The primary axis (HS PCl) of a principal component analysis explained $35.6 \%$ of the variability among lakes and was characterized by lake morphometry (lake surface area and volume). Seepage lakes were relatively deeper and higher in volume compared to drainage and bog lakes (Table 1). Another $27.5 \%$ of variation among lakes was described by the second axis (HS PC2), with strong positive loadings from WA:LA and deciduous forest cover and strong negative loadings from maximum lake depth, lake elevation, and total wetland cover (Figure 2A). Although bogs and drainage lakes had similarly large WA:LA, bog lakes had the smallest watersheds and lake surface areas, and no surface inflows or outflows (except HB which has a small surface outflow with very low flow rates). Bog and seepage lakes were situated at a relatively higher elevation in the landscape compared to drainage lakes (Table 1). Drainage lakes had shorter HRT $(231 \pm 117$ days, mean \pm standard deviation) compared to seepage $(1065 \pm 199)$ and bog lakes $(963 \pm 219$ days). Watershed wetland cover was similarly high for seepage and bog lakes (> 50\%, with the exception of BA) and substantially higher than for drainage lakes.

Hydrologic setting influenced mean solute concentrations and light availability (Mantel $r=0.36$, $p=0.021$; Table 1, Figure 2B). Total N, P, chlorophyll, and DOC concentrations were lowest in seepage lakes (Figure 2B). Concentrations of these solutes were higher in the other two lake types; in particular, bog lakes tended to have high DOC concentrations. DOC concentration was highly correlated with lake color (absorbance at $440 \mathrm{~nm}$; $r=0.93,95 \%$ confidence interval 0.91-0.96), so as DOC increased, light penetration and mixed layer depth decreased. Both bogs and drainage lakes had wide ranges in nutrient $\mathrm{PC} 2$ relative to seepage lakes. While bogs and drainage lakes had similar TP concentrations (95\% confidence interval 18.6-25.0 and 18.6-26.0 ug $\mathrm{L}^{-1}$, respectively), bog lakes had slightly higher TN concentrations (95\% confidence interval 694-856 ug L ${ }^{-1}$ ) than drainage lakes (609800 ug L $^{-1}$ ).

The relationship between total antecedent precipitation and in-lake nutrient concentrations varied among lake types, suggesting different controls on nutrient delivery by hydrologic setting (Figure 3B). Total antecedent precipitation varied substantially among our study years, though most years were wetter than the long-term average, particularly in the spring and summer (Figure 3A, Figure S1). Wetter years were associated with lower TP concentrations in seepage $(r=-0.46$, $p=0.01)$ and bog lakes $(r=-0.47, p=0.01)$, but not in drainage lakes $(r=-0.06, p=0.78)$. In contrast, TN and $\mathrm{abs}_{440}$ were positively correlated with precipitation in seepage (TN: $r=0.38$, $p=0.03 ;$ abs $\left._{440}: r=0.52, p=0.003\right)$ and drainage lakes (TN: $r=0.52, p=0.01 ; \mathrm{abs}_{440}: r=0.43$, $p=0.05$ ), but not in bog lakes (TN: $r=0.16$, $p=0.39 ; \operatorname{abs}_{440}: r=0.29, p=0.12$ ). Only a few individual lakes had a positive correlation between DOC concentrations and precipitation (EL, HB), but wet years were associated with higher $\mathrm{abs}_{440}$ in nearly every lake (Table S1).

Both the mean rates and the interannual variability in GPP and ER differed by hydrologic setting (Figure 4). Seepage lakes had low GPP and ER rates and high variability; drainage lakes had moderate to high rates but low variability; and bog lakes had high rates as well as high variability. Specifically, drainage lakes on average had the lowest acrossyear c.v. for both ER ( $15 \pm 3 \%$, mean \pm standard deviation) and GPP $(14 \pm 4 \%)$. Interannual variability in GPP was higher in seepage $(27 \pm 7 \%)$ and bog lakes $(34 \pm 1 \%)$ than drainage lakes (oneway ANOVA: $\left.\mathrm{F}_{2,8}=4.7, p=0.04\right)$. Interannual variability in ER was also higher in seepage lakes $(37 \pm 7 \%)$ and bog lakes $(41 \pm 1 \%)$ compared to drainage lakes (one-way ANOVA: $\mathrm{F}_{2,8}=7.6$, $p=0.01)$. The relatively low interannual variability in drainage lake ecosystem metabolism may be due to the shorter HRT of drainage lakes compared to bog lakes, despite having similar WA:LA (Figure 4B). Variation in both GPP and ER was positively linearly related to HRT, though the effect was stronger for $\mathrm{ER}\left(\mathrm{F}_{1,9}=47.6 ; \mathrm{R}^{2}=0.84 ; p<0.001\right)$ compared to GPP $\left(\mathrm{F}_{1,9}=7.9 ; \mathrm{R}^{2}=0.47 ; p=0.02\right)$.

Hydrologic setting influenced the degree to which ER and GPP were coupled (Figure 5A). Although GPP and ER were strongly correlated in all lake types (seepage $r=0.84$, drainage $r=0.92$, bog $r=0.82$ ), GPP and NEP were not. NEP was strongly correlated with ER across all lakes (seepage 

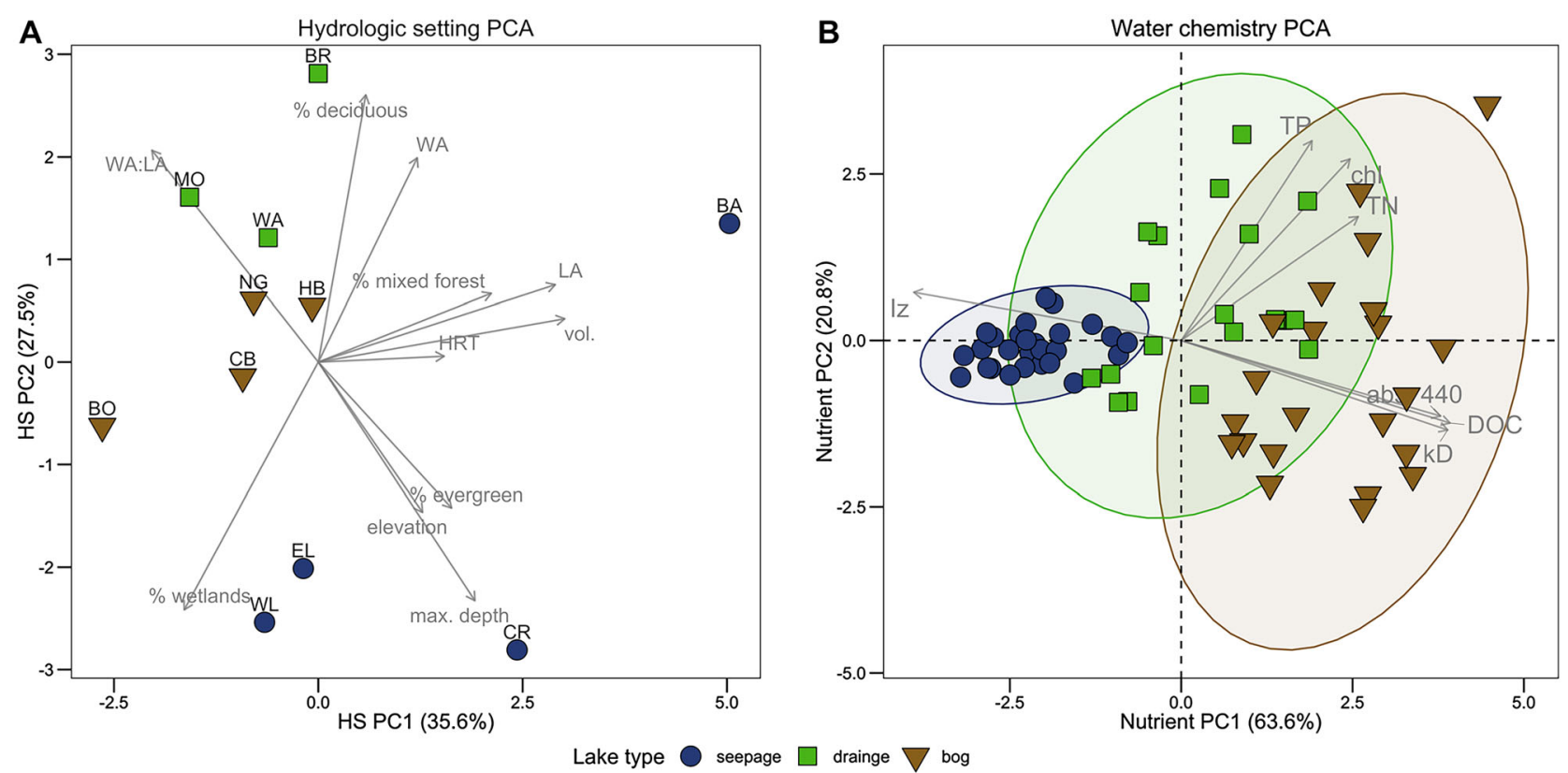

Figure 2. A Seepage, drainage, and bog lakes represent relatively distinct lake types in terms of hydrologic setting (A) and water chemistry and light availability $(\mathbf{B})$. Plots show first two axes from principal components analyses; variance explained by each axis is indicated in parentheses in the axis label. In panel B, each point represents average summer chemical and light parameters for one lake-year $(n=67)$. See Table 1 for variable descriptions.

$r=0.89$, drainage $r=0.48$, bog $r=0.64$ ); consequently, lakes and years with higher ER were also more strongly heterotrophic. Bog lakes, and especially $\mathrm{BO}$ and NG, tended to have high ER relative to GPP; seepage lakes also exhibited a pattern of divergence from the 1:1 in certain years indicating ER outpaced GPP (Figure 5A).

The ER-GPP coupling patterns were consistent with how metabolism of lakes responded to precipitation. ER increased in wet years in all lake types, but GPP increased only in drainage lakes, and only modestly ( $r=0.37, p=0.09$; Figure 5B). Consequently, seepage and bog lakes had more negative NEP in wet years $(r=-0.56, p=0.002$ and $r=-0.48, p=0.01$, respectively), while drainage lakes did not show a consistent association between annual precipitation and NEP because both ER and GPP were simultaneously stimulated. Wet years were associated with dampened productivity in two bog lakes (BO, NG) and one seepage lake (BA; Figure S2).

\section{Discussion}

Hydrologic connectivity and landscape position are perhaps the most important drivers of variation in aquatic ecosystems (Soranno and others 1999, 2019; Read and others 2015). These factors structure spatial differences in water chemistry across lake-rich regions (Kratz and others 1997; Soranno and others 2015; Lapierre and others 2018) as well as variable biogeochemical responses to climatic variability (Soranno and others 1999; Rose and others 2016; Lottig and others 2017). Building on these established relationships, we found that hydrologic setting, or the morphological and landscape features that set the biogeochemical blueprint of a lake ecosystem, predictably structured ambient nutrient concentrations in lakes, and in turn, average rates of metabolism across the landscape. Interannual variation in precipitation altered ecosystem metabolism in ways that differed systematically depending on hydrologic setting. Increases in precipitation drove greater ecosystem respiration for lakes in all hydrologic settings, but only drainage lakes showed a subtle response of primary production (GPP) to increased precipitation. This resulted in strong responses of NEP to precipitation for seepage and bog lakes, but not drainage lakes. Overall, lakes with longer hydrologic residence time (seepage and bog lakes) were more sensitive to variation in precipitation than those with short hydrologic residence times (drainage lakes). Considering the hydrologic setting of a waterbody may provide context for why heterogenous responses to a common stressor are often observed across lakes in a landscape (O'Reilly and others 2015; Zwart and others 2019). Below, 

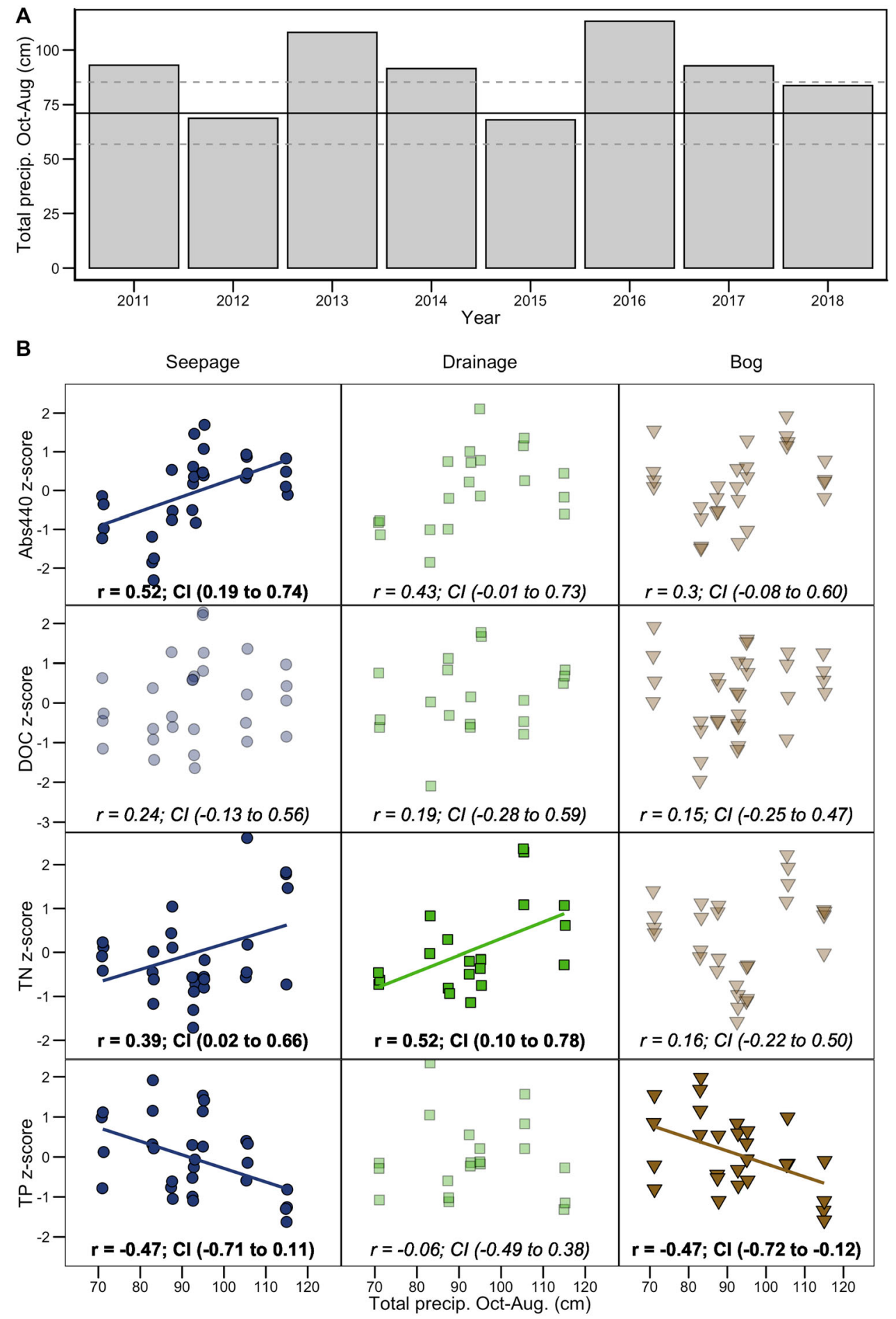

Figure 3. A Total antecedent precipitation (previous October to current August, inclusive) for each of the study years. Horizontal lines indicate 1980-2010 average \pm standard deviation. B Correlations between total antecedent precipitation and $\mathrm{abs}_{440}, \mathrm{DOC}, \mathrm{TP}$, and TN. Dark points and bold text indicate $95 \%$ confidence intervals (CI) for the correlation coefficients that do not overlap zero. Response variables were scaled for easier comparison. 


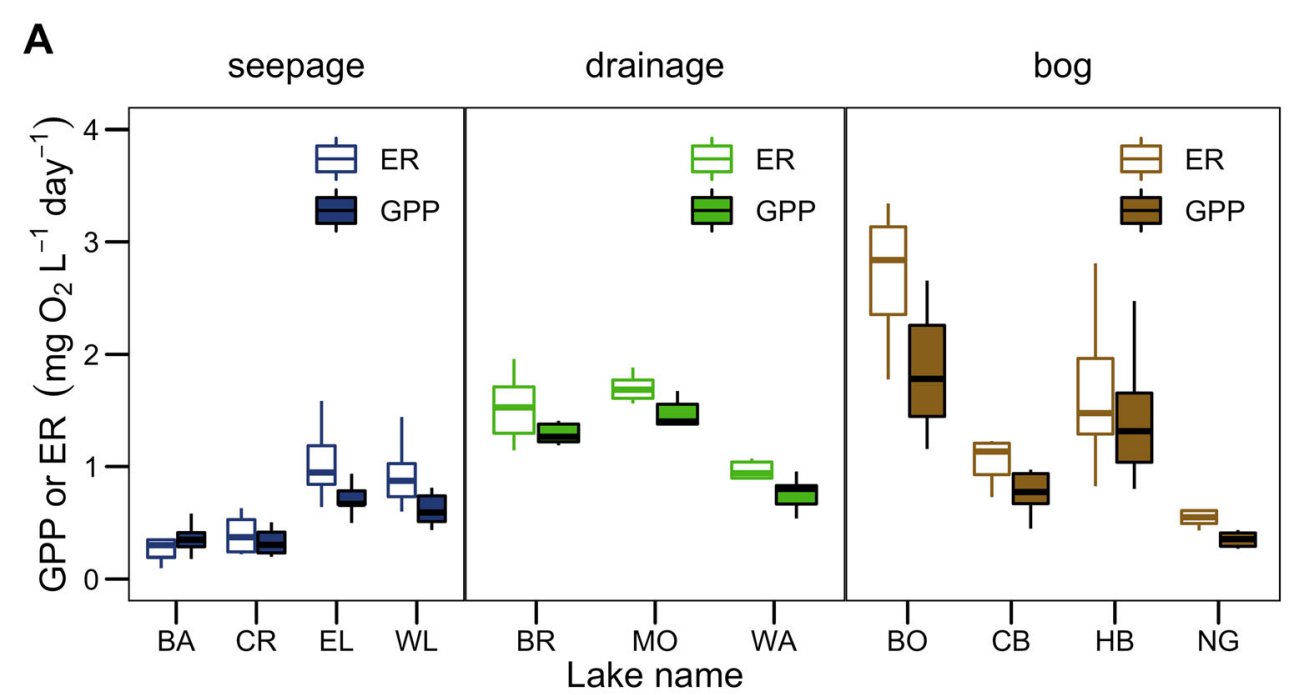

B

\section{C}

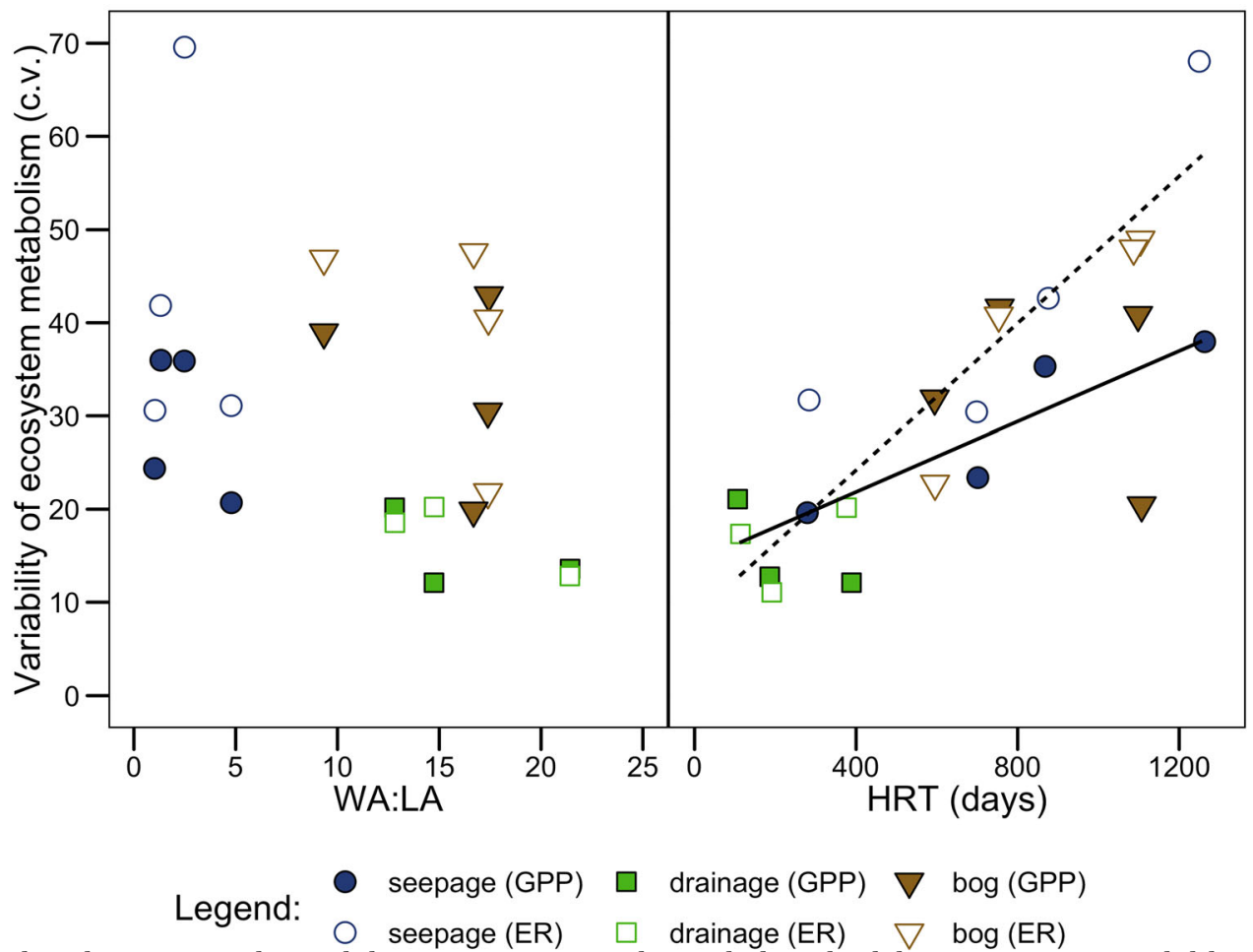

Figure 4. Spatial and interannual variability in mean annual metabolism by lake type. A GPP (solid boxplots) and ER (hollow boxplots) by lake and lake type for all years in which metabolism was estimated. B and C Interannual variability in GPP and ER (coefficient of variation, c.v.) plotted against the ratio of watershed area to lake area (B) and against hydrologic residence time $(\mathbf{C})$. Linear relationships between interannual variability and average hydrologic residence time are shown for GPP (dashed line) and ER (solid line).

we elaborate on our results, discuss potential mechanisms underpinning these patterns, and propose how insights from our study system may be applied in other settings.

We found that in lake $\mathrm{N}$ and $\mathrm{P}$ responses to annual precipitation varied as a function of hydrologic setting (Figure 3B). Similar patterns of asyn- chronous $\mathrm{N}$ and $\mathrm{P}$ dynamics have been reported in other studies of hydrologically complex landscapes or biologically reactive solutes (Webster and others 2000; Cardille and others 2007; Oliver and others 2017). In contrast, lake color ( abs $_{440}$ ) was darker in wet years in almost every lake, but DOC concentrations were fairly stable. This is consistent with 

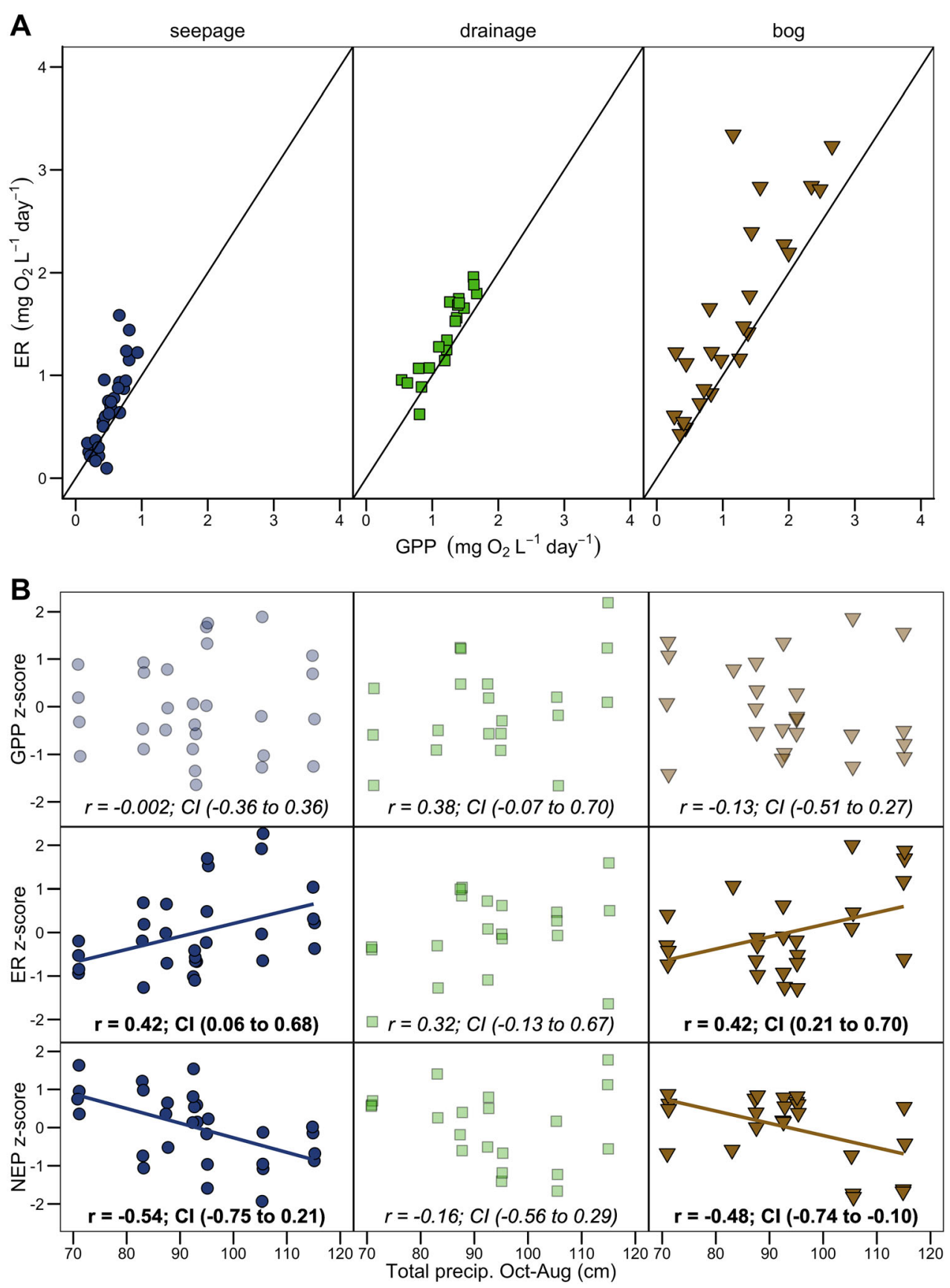

Figure 5. A ER versus GPP for each lake type, with 1:1 line. Points are mean values for each lake-year. B Correlations between total antecedent precipitation (previous October to current August) and GPP, ER, and NEP for each lake type. Dark points and bold text indicate $95 \%$ confidence intervals (CI) for the correlation coefficients that do not overlap zero.

previous work showing the responsiveness of DOC quality to climatic variation (Figure 3B; Kellerman and others 2014; Jane and others 2017). These patterns of solute and terrestrial organic matter variability, and the mechanisms that underlie their temporal variability, may also explain metabolic responses across lakes of contrasting hydrologic settings.
We found that net heterotrophy was the norm in all of our lakes, but the degree of heterotrophy and the coupling between ER and GPP varied by hydrologic setting. Ecosystem respiration was positively related to annual precipitation regardless of hydrologic setting, likely supported by the overall increase in terrestrial organic material delivered via hydrological inflows (Dillon and Molot 1997; Wilkinson and others 2013; Zarnetske and others 
2018; Williamson and others 2020). Gross primary production, however, responded differently to variation in precipitation and depended on hydrologic setting (Figure 5). Lakes draining large landscapes with short residence times (drainage lakes) were the only lake types where summer GPP increased with annual precipitation, likely owing to larger nutrient loads (Brett and others 2012; Jones and others 2018; Zwart and others 2018). The absence of a consistent GPP response to greater annual precipitation in seepage and bog lakes may reflect overall low nutrient loads for seepage lakes (Zwart and others 2018) and light-limiting effects of DOC in bog lakes (Kelly and others 2018). Because ER and GPP in drainage lakes increased in tandem as precipitation increased these systems had relatively invariable NEP through time.

There are a few different mechanisms by which hydrologic setting contributes to differential responses of GPP to variation in annual precipitation. Terrestrial-aquatic connectivity ultimately plays a role in the differential delivery and availability of nutrients in the landscape mosaic (Martin and Soranno 2006; Fergus and others 2017), and contrasting flow paths of water in various hydrologic settings result in variable yields and quality of dissolved and particulate nutrients (Bertolet and others 2018; Jepsen and others 2019). For example, in bogs and seepage lakes, precipitation was consistently negatively correlated with TP but positively correlated with $\mathrm{TN}$, possibly because of the higher concentrations of organic nitrogen or ammonium export associated with high wetland cover (Alvarez-Cobelas and others 2008; Sponseller and others 2018) or higher mobility of $\mathrm{N}$ relative to $\mathrm{P}$ in flat watersheds (Goyette and others 2019). Although $\mathrm{N}$ and $\mathrm{P}$ are often concurrently delivered with terrestrial OM loads (Corman and others 2018), precipitation delivers colored terrestrial OM loads that then serve to limit primary production via light limitation where ambient DOC concentrations are already high (Kelly and others 2018). Terrestrial organic matter loads in wet years can also reduce the average light climate in the upper mixed layer, suppressing GPP (Zwart and others 2016). Relative to ecosystem respiration, the controls on temporal variability in gross primary production are much more dependent on hydrologic setting and warrant further investigation.

The sensitivity of metabolism to interannual variability in precipitation can be understood after accounting for the influence of landscape position, WA:LA, and hydrological residence time. Residence time and WA:LA appear to be important aspects of hydrologic setting for determining interannual variability in ecosystem metabolism. Seepage and bog lakes, with long HRT and relatively high landscape position, were twice as variable as drainage lakes that had short HRT (Figure 4B). The longer residence times of bog lakes likely allowed for more time to process solutes delivered from the landscape in wet years, resulting in greater interannual variation in metabolism, and potential for 'lag' effects from previous seasons or years. In contrast, though hydrologic loads are high in lakes drainage lakes (high WA:LA), biogeochemical processes may be time-limited because some proportion of the nutrients and dissolved organic matter are transported downstream before they can be fully mineralized, assimilated, or buried (Hanson and others 2014; Vachon and others 2020). Ultimately, while lakes with short HRT may be highly reactive on short-time scales (Hotchkiss and others 2018; Jones and others 2018), over longer timescales short HRT begets a rapid return from perturbed conditions (Jennings and others 2012; Klug and others 2012). In long HRT lakes, the relative importance of internal processes regulating biogeochemical dynamics and the probability of biogeochemical transformation increases (Vachon and others 2017a, 2017b; Jones and others 2018). Consequently, lakes with longer residence times and smaller WA:LA may be more sensitive to variability in hydrologic and nutrient loads (Figure 5).

\section{A Framework for Understanding Climate Impacts on Lake Ecosystem Metabolism}

We speculate that the relationship that we observed between residence time and the sensitivity of metabolism to interannual climate variability may be generalizable across lake ecosystems (Figure 6). In short HRT lakes dominated by fluvial processes, nutrient loads are large and instantaneous biogeochemical rates are high, but retention of organic matter and nutrients is low (Brett and Benjamin 2008; Harrison and others 2009; Finlay and others 2013). In these short HRT lakes, we hypothesize that interannual variability in GPP and ER may not deviate strongly from the mean because processing of nutrients is time-limited and not transport- limited. For instance, following a disturbance such as a pulse of nutrients washing in from a storm, a short HRT system should rapidly return to its pre-disturbance state because of high flushing rates (DeAngelis 1980). Thus, we predict that lakes with short HRT are not as sensitive to variation in precipitation as lakes with longer HRT, even though interannual nutrient loads may vary 
considerably. Groundwater inputs may also play a role in stabilizing solute concentrations and water levels (Webster and others 1996), and in turn, may contribute to low variability in ecosystem metabolism, particularly in low-relief and formerly glaciated landscapes where groundwater is an important component of water budgets (Hanson and others 2018).

In contrast, in intermediate HRT lakes with small WA:LA, loads of water and matter are relatively low resulting in low instantaneous biogeochemical rates, but overall high retention of organic matter and nutrients. As HRT increases, evaporation, which does not transport matter, becomes an important hydrologic loss; this is particularly true in lakes lacking surface outflows. In dry seasons or years when hydrologic inflows decrease, chemical residence time can become further decoupled from hydrologic residence time. In wet years, the supply of solutes and organic matter is renewed and, relative to short HRT lakes, long HRT lakes have more time to process what little nutrients and solutes are delivered from the surrounding watershed. Thus, along a gradient of increasing HRT, lake ecosystem metabolism may become more sensitive to climateinduced changes in hydrologic inflows (Figure 1).

Recent estimates of hydrologic residence times in lakes suggest lakes globally vary by about five orders of magnitude (Messager and others 2016), but our lakes span only span about half the range of global HRT estimates. In this dataset, metabolic variability increased roughly linearly as a function

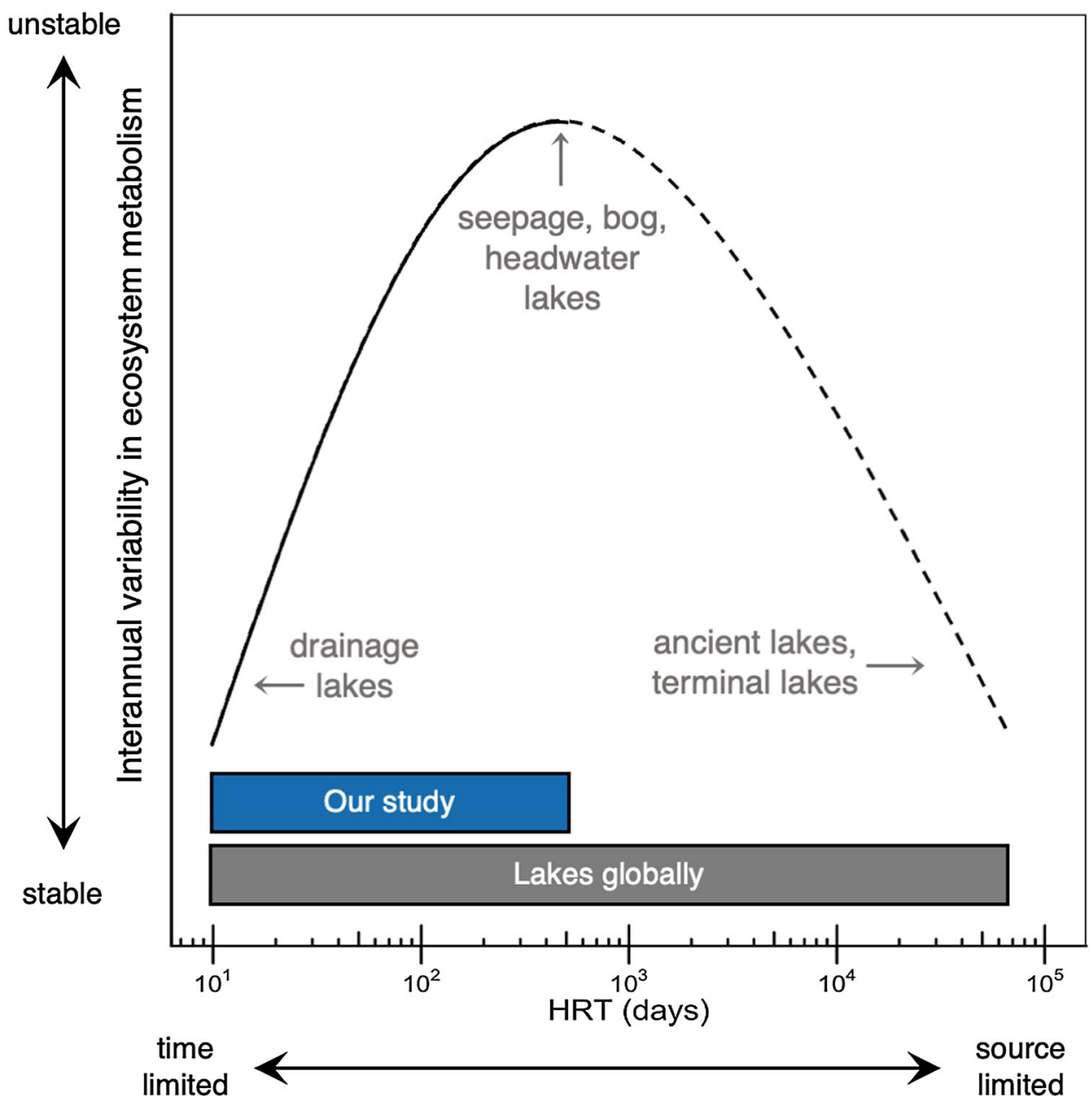

Figure 6. A conceptual figure illustrating the hypothesized relationship between temporal variability in ecosystem metabolism as a function of increasing hydrologic residence time (HRT). In our study variability in mean metabolic rates (May-Aug, annually) increases as a function of increasing HRT. However, we hypothesize that along a gradient of HRT spanning several orders of magnitude, lakes at intermediate HRT would tend to have higher variability while lakes at extreme ends of the spectrum are relatively stable due to time-limitation (short HRT lakes) or source-limitation (long HRT) of biogeochemical processes. 
of increasing HRT, but we hypothesize that in lakes with extremely long residence times (several years to decades) biogeochemical cycling is transportlimited but time-unlimited (Figure 6). In these voluminous lakes, with extremely long HRT (for example, ancient rift lakes, terminal lakes) and small WA:LA, dilution by the large volume of the lake may diminish the effect of any pulse inputs. Further, nutrient chemistry and water clarity likely integrate across several years of variation in climate and hydrologic loads. Although these systems undoubtedly exhibit within-year variation in metabolism related to lake mixing, light availability, and other internally mediated processes (Goldman and Jassby 1990; MacIntyre 2013), year-to-year variability in ecosystem metabolism may be relatively insensitive to short-term variability in climate.

Though we examined a group of lakes in one small geographic region, the patterns we observed might hold in other hydrogeomorphic settings (Soranno and others 1999). Our reasoning is that the hydrological processes that dictate the movement of water and solutes to and through aquatic ecosystems play a major role in controlling rates and extents of biogeochemical transformations everywhere (Covino 2017; Soranno and others 2019). However, we do note that it is difficult to disentangle the stabilizing effect of groundwater gain and short residence times in our study, and it would be interesting to test this framework in drainage lakes in mountainous watersheds where groundwater comprises a small proportional of the overall water budget. Another limitation of developing this framework from a set of lakes in a relatively pristine area is the omission of other key properties that that can influence the variability of ecosystem metabolism aside from HRT. For example, land use (for example, agricultural activity, wetland loss) and hydrological disturbances (for example, flow regime modifications) can impact the transport capacity of a watershed, and in turn modify the nutrient loads into lakes (Fraterrigo and Downing 2008); this may result in higher variability in nutrient concentrations relative to what would be predicted based on WA:LA and HRT in less impacted regions, like the NHLD.

\section{ConClusion}

This current era of rapidly changing climate and land use necessitates a framework for assessing how lake metabolism will respond to ongoing environmental change, both across space and through time. In regions heavily impacted by direct human activity, intensification of the hydrologic cycle will likely interact with changing land use to alter hydrologic inflows, nutrient loads, and in turn tributary nutrient concentrations (Davis and others 2015). Incorporating information about the hydrologic setting of a waterbody into predictive models may help contextualize the spatial patterns of freshwaters and the dynamic patterns of ecosystem processes within them. Considering water bodies along gradients of residence time, a key property of hydrologic setting, may lead to insights into differences in temporal variability in metabolism. A deeper understanding of the dominant drivers of lake metabolism in space and time, and the processes that mediate that variability, will ultimately lead to better predictions of the role of inland waters in global biogeochemical cycles.

\section{ACKNOWLEDGEMENTS}

We acknowledge, with deep respect and gratitude, that the lakes we studied are on the traditional and ancestral homelands of the Lac du Flambeau band of Chippewa and Ojibwe peoples, past and present, who have ongoing cultural and spiritual connections to the area, including the land, waterways, and their inhabitants. We thank the University of Notre Dame (UND) Environmental Research Center for hosting our experiment. The chemical analyses were conducted at the Center for Environmental Science and Technology at UND. Brittni Bertolet, Jim Coloso, Katie Saunders, Alex Ross, Jake Zwart, and Carly Olson contributed to data collection. Input from an anonymous reviewer significantly improved an early version of this manuscript. This work was supported by the National Science Foundation under awards DEB1547866, DEB-1754363, and DEB-1754561.

\section{OPEN ACCESS}

This article is licensed under a Creative Commons Attribution 4.0 International License, which permits use, sharing, adaptation, distribution and reproduction in any medium or format, as long as you give appropriate credit to the original author(s) and the source, provide a link to the Creative Commons licence, and indicate if changes were made. The images or other third party material in this article are included in the article's Creative Commons licence, unless indicated otherwise in a credit line to the material. If material is not included in the article's Creative Commons licence and your intended use is not permitted by statutory regulation or exceeds the permitted use, you will 
need to obtain permission directly from the copyright holder. To view a copy of this licence, visit $h$ ttp://creativecommons.org/licenses/by/4.0/.

\section{DATA AVAILABILITY}

Data are available at https://doi.org/10.25390/cary institute.7438598.v4.

\section{REFERENCES}

Adrian R, O'Reilly CM, Zagarese H, Baines SB, Hessen DO, Keller W, Livingstone DM, Sommaruga R, Straile D, Donk EV, Weyhenmeyer GA, Winder M. 2009. Lakes as sentinels of climate change. Limnol Oceanogr 54:2283-2297.

Alvarez-Cobelas M, Angeler DG, Sánchez-Carrillo S. 2008. Export of nitrogen from catchments: A worldwide analysis. Environ Pollut 156:261-269.

Anderson MJ. 2001. A new method for non-parametric multivariate analysis of variance. Austral Ecol 26:32-46.

Bernhardt ES, Heffernan JB, Grimm NB, Stanley EH, Harvey J, Arroita M, Appling AP, Cohen M, McDowell WH, Hall R Jr, et al. 2018. The metabolic regimes of flowing waters. Limnol Oceanogr 63:S99-118.

Bertolet BL, Corman JR, Casson NJ, Sebestyen SD, Kolka RK, Stanley EH. 2018. Influence of soil temperature and moisture on the dissolved carbon, nitrogen, and phosphorus in organic matter entering lake ecosystems. Biogeochemistry 139:293305.

Bogard MJ, St-gelais NF, Vachon D, Giorgio PA. 2020. Patterns of Spring / Summer Open-Water Metabolism Across Boreal Lakes. Ecosystems. https://doi.org/10.1007/s10021-020-0048 7-7.

Brett MT, Arhonditsis GB, Chandra S, Kainz MJ. 2012. Mass flux calculations show strong allochthonous support of freshwater zooplankton production is unlikely. PloS One 7:e39508.

Brett MT, Benjamin MM. 2008. A review and reassessment of lake phosphorus retention and the nutrient loading concept. Freshwater Biol 53:194-211.

Cardille JA, Carpenter SR, Coe MT, Foley JA, Hanson PC, Turner MG, Vano JA. 2007. Carbon and water cycling in lake-rich landscape connections, lake hydrology, and biogeochemistry. J Geophys Res: Biogeosci 112:1-18.

Cheng FY, Basu NB. 2017. Biogeochemical hotspots: Role of small water bodies in landscape nutrient processing. Water Resour Res 53:5038-5056.

Collins SM, Yuan S, Tan PN, Oliver SK, Lapierre JF. 2019. Winter precipitation and summer temperature predict lake water quality at macroscales water resources research. Water Resour Res 55:2708-2721.

Corman JR, Bertolet BL, Casson NJ, Sebestyen SD, Kolka RK, Stanley EH. 2018. Nitrogen and phosphorus loads to temperate seepage lakes associated with allochthonous dissolved organic carbon loads. Geophys Res Lett 45:5481-5490.

Covino T. 2017. Hydrologic connectivity as a framework for understanding biogeochemical flux through watersheds and along fluvial networks. Geomorphology 277:133-144.

Davis J, O'Grady AP, Dale A, Arthington AH, Gell PA, Driver PD, Bond N, Casanova M, Finlayson M, Watts RJ, et al. 2015. When trends intersect: The challenge of protecting freshwater ecosystems under multiple land use and hydrological intensification scenarios. Sci Total Environ 534:65-78.

DeAngelis D. 1980. Energy flow, nutrient cycling, and ecosystem resilience. Ecology 61:764-771.

del Giorgio PA, Peters RH. 1994. Patterns in planktonic P: R ratios in lakes: Influence of lake trophy and dissolved organic carbon. Limnology and Oceanography 39:772-787.

Dillon PJ, Molot LA. 1997. Dissolved organic and inorganic carbon mass balances in central Ontario lakes. Biogeochemistry 36:29-42.

Dodds WK, Bruckerhoff L, Batzer D, Schechner A, Pennock C, Renner E, Tromboni F, Bigham K, Grieger S. 2019. The freshwater biome gradient framework: predicting macroscale properties based on latitude, altitude, and precipitation. Ecosphere 10:e02786.

Drake TW, Raymond PA, Spencer RGM. 2018. Terrestrial carbon inputs to inland waters: a current synthesis of estimates and uncertainty. Limnology and Oceanography Letters 3:132-142.

Fay P, Blair J, Smith M, Nippert J, Carlisle J, Knapp A, Zona D. 2011. Relative effects of precipitation variability and warming on tallgrass prairie ecosystem function. Biogeosciences 8:3053-3068.

Fergus CE, Lapierre J-F, Oliver SK, Skaff NK, Cheruvelil KS, Webster K, Scott C, Soranno P. 2017. The freshwater landscape: lake, wetland, and stream abundance and connectivity at macroscales. Ecosphere 8:e01911.

Finlay JC, Small GE, Sterner RW. 2013. Human influences on nitrogen removal in lakes. Science 342:247-251.

Fraterrigo JM, Downing JA. 2008. The Influence of Land Use on Lake Nutrients Varies with Watershed Transport Capacity. Ecosystems 11:1021-1034.

Gesch DB, Evans GA, Oimoen MJ, Arundel S. 2018. The National Elevation Dataset. In: American Society for Photogrammetry and Remote Sensing. pp 83-110. http://pubs.er. usgs.gov/publication/70201572

Goldman CR, Jassby A. 1990. Spring mixing depth as a determinant of annual primary production in lakes. In: Large Lakes. Springer. pp 125-32.

Goyette J-O, Bennett EM, Maranger R. 2019. Differential influence of landscape features and climate on nitrogen and phosphorus transport throughout the watershed. Biogeochemistry 142:155-174.

Groisman PY, Knight RW, Karl TR. 2012. Changes in intense precipitation over the central United States. J Hydrometeorol 13:47-66.

Hanson PC, Bade DL, Carpenter SR, Kratz TK. 2003. Lake metabolism: relationships with dissolved organic carbon and phosphorus. Limnol Oceanogr 48:1112-1119.

Hanson PC, Pace ML, Carpenter SR, Cole JJ, Stanley EH. 2014. Integrating landscape carbon cycling: research needs for resolving organic carbon budgets of lakes. Ecosystems 18:363-375.

Hanson ZJ, Zwart JA, Vanderwall J, Solomon CT, Jones SE, Hamlet AF, Bolster D. 2018. Integrated, regional-scale hydrologic modeling of inland lakes. J Am Water Resour AsSoc 54:1302-1324.

Harrison JA, Maranger RJ, Alexander RB, Giblin AE, Jacinthe PA, Mayorga E, Seitzinger SP, Sobota DJ, Wollheim WM. 2009. The regional and global significance of nitrogen removal in lakes and reservoirs. Biogeochemistry 93:143-157.

Hart E, Bell K. 2015. Prism: Access Data From The Oregon State Prism Climate Project. Zenodo https://zenodo.org/record/336 63. Last accessed 31/08/2020 
Held IM, Soden BJ. 2006. Robust responses of the hydrological cycle to global warming. J Climate 19:5686-5699.

Homer C, Dewitz J, Jin S, Xian G, Costello C, Danielson P, Gass L, Funk M, Wickham J, Stehman S, et al. 2020. Conterminous United States land cover change patterns 2001-2016 from the 2016 National Land Cover Database. ISPRS J Photogramm Remote Sens 162:184-199.

Hosen JD, Aho KS, Appling AP, Creech E, Fair JH, Hall R Jr, Kyzivat E, Lowenthal R, Matt S, Morrison J, et al. 2019. Enhancement of primary production during drought in a temperate watershed is greater in larger rivers than headwater streams. Limnol Oceanogr 64:1458-1472.

Hotchkiss ER, Sadro S, Hanson PC. 2018. Toward a more integrative perspective on carbon metabolism across lentic and lotic inland waters. Limnol Oceanogr Lett 3:57-63.

Howarth RW, Swaney DP, Butler TJ, Marino R. 2000. Rapid communication: climatic control on eutrophication of the hudson river estuary. Ecosystems 3:210-215.

Hsu JS, Powell J, Adler PB. 2012. Sensitivity of mean annual primary production to precipitation. Global Change Biol 18:2246-2255.

Jackson MC, Loewen CJ, Vinebrooke RD, Chimimba CT. 2016. Net effects of multiple stressors in freshwater ecosystems: a meta-analysis. Global Change Biol 22:180-189.

Jane SF, Winslow LA, Remucal CK, Rose KC. 2017. Long-term trends and synchrony in dissolved organic matter characteristics in Wisconsin, USA, lakes: Quality, not quantity, is highly sensitive to climate. J Geophys Res Biogeosciences 122:546561.

Jennings E, Jones S, Arvola L, Staehr PA, Gaiser E, Jones ID, Weathers KC, Weyhenmeyer GA, Chiu C-Y, Eyto ED. 2012. Effects of weather-related episodic events in lakes: an analysis based on high-frequency data. Freshwater Biol 57:589-601.

Jepsen SM, Harmon TC, Sadro S, Reid B, Chandra S. 2019. Water residence time (age) and flow path exert synchronous effects on annual characteristics of dissolved organic carbon in terrestrial runoff. Sci Total Environ 656:1223-1237.

Jones SE, Zwart JA, Kelly PT, Solomon CT. 2018. Hydrologic setting constrains lake heterotrophy and terrestrial carbon fate. Limnology and Oceanography Letters 3:256-264.

Kellerman AM, Dittmar T, Kothawala DN, Tranvik LJ. 2014. Chemodiversity of dissolved organic matter in lakes driven by climate and hydrology. Nat Commun 5:1-8.

Kelly PT, Solomon CT, Zwart JA, Jones SE. 2018. A Framework for Understanding Variation in Pelagic Gross Primary Production of Lake Ecosystems. Ecosystems 21:1364-1376.

Kissman CEH, Williamson CE, Rose KC, Saros JE. 2017. Nutrients associated with terrestrial dissolved organic matter drive changes in zooplankton:phytoplankton biomass ratios in an alpine lake. Freshwater Biol 62:40-51.

Kitchell JF, Carpenter SR. 1993. Variability in Lake Ecosystems: Complex Responses by the Apical Predator. In: McDonnell MJ, Pickett STA, editors. Humans as Components of Ecosystems. New York, NY: Springer New York. pp 111-24.

Klug JL, Richardson DC, Ewing HA, Hargreaves BR, Samal NR, Vachon D, Pierson DC, Lindsey AM, Odonnell DM, Effler SW, Weathers KC. 2012. Ecosystem effects of a tropical cyclone on a network of lakes in northeastern North America. Environ Sci Technol 46:11693-11701.

Kratz TK, Benson BJ, Blood ER, Cunningham GL, Dahlgren RA. 1991. the influence of landscape position on temporal vari- ability in four north American ecosystems. Am Naturalist 138:355-378.

Kratz T, Webster K, Bowser C, Meguson J, Benson B. 1997. The influence of landscape position on lakes in northern Wisconsin. Freshwater Biol 37:209-217.

Laas A, Nõges P, Kõiv T, Nõges T. 2012. High-frequency metabolism study in a large and shallow temperate lake reveals seasonal switching between net autotrophy and net heterotrophy. Hydrobiologia 694:57-74.

Lapierre JF, Collins SM, Seekell DA, Spence Cheruvelil K, Tan PN, Skaff NK, Taranu ZE, Fergus CE, Soranno PA. 2018. Similarity in spatial structure constrains ecosystem relationships: Building a macroscale understanding of lakes. Glob Ecol Biogeogr 27:1251-1263.

Lê S, Josse J, Husson F. 2008. FactoMineR: A package for multivariate analysis. J Stat Softw 25:1-18.

Lindsay JB. 2016. Whitebox GAT: a case study in geomorphometric analysis. Comput Geosciences 95:75-84.

Lottig NR, Buffam I, Stanley EH. 2013. Comparisons of wetland and drainage lake influences on stream dissolved carbon concentrations and yields in a north temperate lake-rich region. Aquatic Sci 75:619-630.

Lottig NR, Tan P-N, Wagner T, Cheruvelil KS, Soranno PA, Stanley EH, Scott CE, Stow CA, Yuan S. 2017. Macroscale patterns of synchrony identify complex relationships among spatial and temporal ecosystem drivers. Ecosphere 8:e02024.

MacIntyre S. 2013. Climatic variability, mixing dynamics, and ecological consequences in the African Great Lakes. Climatic change and global warming of inland waters: Impacts and mitigation for ecosystems and societies Wiley:311-36.

Martin SL, Soranno PA. 2006. Lake landscape position: relationships to hydrologic connectivity and landscape features. Limnol Oceanogr 51:801-814.

McCullough IM, Cheruvelil KS, Collins SM, Soranno PA. 2019. Geographic patterns of the climate sensitivity of lakes. Ecol Appl 0:e01836.

Melillo JM, Callaghan TV, Woodward FI, Salati E, Sinha SK 1990. Effects on ecosystems. In: Climate change: The IPCC scientific assessment. pp 283-310.

Menzel DW, Corwin N. 1965. The measurement of total phosphorus in seawater based on the liberation of organically bound fractions by persulfate oxidation. Limnol Oceanogr 10:280-282.

Messager ML, Lehner B, Grill G, Nedeva I, Schmitt O. 2016. Estimating the volume and age of water stored in global lakes using a geo-statistical approach. Nat Commun 7:13603.

Oksanen J, Blanchet FG, Friendly M, Kindt R, Legendre P, McGlinn D, Minchin PR, O'Hara RB, Simpson GL, Solymos P, Stevens MHH, Szoecs E, Wagner H. 2019. vegan: Community Ecology Package. https://CRAN.R-project.org/package=vegan

Oleksy IA, Beck WS, Lammers RW, Steger CE, Wilson C, Christianson K, Vincent K, Johnson G, Johnson PTJ, Baron JS. 2020. The role of warm, dry summers and variation in snowpack on phytoplankton dynamics in mountain lakes. Ecology 101:1-12.

Oliver SK, Collins SM, Soranno PA, Wagner T, Stanley EH, Jones JR, Stow CA, Lottig NR. 2017. Unexpected stasis in a changing world: Lake nutrient and chlorophyll trends since 1990. Global Change Biol 23:5455-5467.

Olsen KK. 2008. Multiple wavelength ultraviolet determinations of nitrate concentration, method comparisons from the 
Preakness Brook monitoring project, October 2005 to October 2006. Water Air Soil Pollut 187:195-202.

O'Reilly CM, Sharma S, Gray DK, Hampton SE, Read JS, Rowley RJ, Schneider P, Lenters JD, McIntyre PB, Kraemer BM, Weyhenmeyer GA, Straile D, Dong B, Adrian R, Allan MG, Anneville O, Arvola L, Austin J, Bailey JL, Baron JS, Brookes JD, de Eyto E, Dokulil MT, Hamilton DP, Havens K, Hetherington AL, Higgins SN, Hook S, Izmest'eva LR, Joehnk KD, Kangur K, Kasprzak P, Kumagai M, Kuusisto E, Leshkevich G, Livingstone DM, MacIntyre S, May L, Melack JM, MuellerNavarra DC, Naumenko $M$, Noges $P$, Noges $T$, North RP, Plisnier P-D, Rigosi A, Rimmer A, Rogora M, Rudstam LG, Rusak JA, Salmaso N, Samal NR, Schindler DE, Schladow SG, Schmid M, Schmidt SR, Silow E, Soylu ME, Teubner K, Verburg P, Voutilainen A, Watkinson A, Williamson CE, Zhang G. 2015. Rapid and highly variable warming of lake surface waters around the globe: GLOBAL LAKE SURFACE WARMING. Geophys Res Lett 42:10773-10781.

Peterson GD, Beard TD, Beisner BE, Bennett EM, Carpenter SR, Cumming GS, Dent CL, Havlicek TD. 2003. Assessing Future Ecosystem Services: a Case Study of the Northern Highlands Lake District, Wisconsin. Conservation Ecology 7.

PRISM Climate Group. 2020 Oregon State University. http:// prism.oregonstate.edu

R Core Team. 2019. R: A Language and Environment for Statistical Computing. Vienna, Austria: R Foundation for Statistical Computing https://www.R-project.org/

Read EK, Patil VP, Oliver SK, Hetherington AL, Brentrup JA, Zwart JA, Winters KM, Corman JR, Nodine ER, Woolway RI, et al. 2015. The importance of lake-specific characteristics for water quality across the continental United States. Ecol Appl 25:943-955.

Richardson DC, Carey CC, Bruesewitz DA, Weathers KC. 2016. Intra- and inter-annual variability in metabolism in an oligotrophic lake. Aquatic Sci 79:319-333.

Rose KC, Greb SR, Diebel M, Turner MG. 2016. Annual precipitation regulates spatial and temporal drivers of lake water clarity. Ecol Appli 27:632-643.

Schiff S, Aravena R, Mewhinney E, Elgood R, Warner B, Dillon P, Trumbore S. 1998. Precambrian shield wetlands: hydrologic controls of the sources and export of dissolved organic matter. Climatic Change 40:167-188.

Solomon C, Jones SE, Weidel B, Bertolet B, Bishop C, Coloso J. 2018. MFE database: Data from ecosystem ecology research by Jones, Solomon, and collaborators on the ecology and biogeochemistry of lakes and lake organisms in the Upper Midwest, USA. https://doi.org/10.25390/caryinstitute.7438598. v4. Last accessed 26/05/2021

Solomon CT, Bruesewitz D, Richardson D, Rose K, Van de Bogert M, Hanson P, Kratz T, Larget B, Adrian R, Babin B, Chiu C-Y, Hamilton D, Gaiser E, Hendricks S, Istvanovics V, Laas A, O'Donnell D, Pace M, Ryder E, Staehr P, Torgersen T, Vanni M, Weathers K, Zhu G. 2013. Ecosystem respiration: Drivers of daily variability and background respiration in lakes around the globe. Limnol Oceanogr 58:849-866.

Soranno PA, Cheruvelil KS, Wagner T, Webster KE, Bremigan MT. 2015. Effects of land use on lake nutrients: the importance of scale, hydrologic connectivity, and region. PloS ONE 10:e135454.

Soranno PA, Wagner T, Collins SM, Lapierre J-F, Lottig NR, Oliver SK. 2019. Spatial and temporal variation of ecosystem properties at macroscales. Ecol Lett 22:1587-1598.
Soranno PA, Webster KE, Riera JL, Kratz TK, Baron JS, Bukaveckas PA, Kling GW, White DS, Caine N, Lathrop RC, Leavitt PR. 1999. Spatial variation among lakes within landscapes: ecological organization along lake chains. Ecosystems 2:395410.

Sponseller RA, Blackburn M, Nilsson MB, Laudon H. 2018. Headwater mires constitute a major source of nitrogen $(\mathrm{N})$ to surface waters in the boreal landscape. Ecosystems 21:31-44.

Tranvik LJ, Downing JA, Cotner JB, Loiselle SA, Striegl RG, Ballatore TJ, Dillon P, Finlay K, Fortino K, Knoll LB, Kortelainen PL, Kutser T, Larsen S, Laurion I, Leech DM, McCallister SL, McKnight DM, Melack JM, Overholt E, Porter JA, Prairie Y, Renwick WH, Roland F, Sherman BS, Schindler DW, Sobek S, Tremblay A, Vanni MJ, Verschoor AM, von Wachenfeldt E, Weyhenmeyer GA. 2009. Lakes and reservoirs as regulators of carbon cycling and climate. Limnol Oceanogr $54: 2298-2314$.

U.S. Geologic Survey. 2020. USGS TNM Hydrography (NHD).

Vachon D, Del Giorgio PA. 2014. Whole-lake $\mathrm{CO}_{2}$ dynamics in response to storm events in two morphologically different lakes. Ecosystems 17:1338-1353.

Vachon D, Prairie YT, Guillemette F, del Giorgio PA. 2017a. Modeling allochthonous dissolved organic carbon mineralization under variable hydrologic regimes in boreal lakes. Ecosystems 20:781-795.

Vachon D, Solomon CT, del Giorgio PA. 2017b. Reconstructing the seasonal dynamics and relative contribution of the major processes sustaining $\mathrm{CO} 2$ emissions in northern lakes. Limnol Oceanogr 62:706-722.

Vachon D, Sponseller RA, Karlsson J. 2020. Integrating carbon emission, accumulation, and transport in inland waters to understand their role in the global carbon cycle. Global Change Biol 27:719-727.

Webster KE, Kratz TK, Bowser CJ, Magnuson JJ, Rose WJ. 1996. The influence of landscape position on lake chemical responses to drought in northern Wisconsin. Limnol Oceanogr 41:977-984.

Webster KE, Soranno PA, Baines SB, Kratz TK. 2000. Structuring features of lake districts: landscape controls on lake chemical responses to drought. Freshwater Biol 43:499-515.

Welschmeyer NA. 1994. Fluorometric analysis of chlorophyll a in the presence of chlorophyll $\mathrm{b}$ and pheopigments. Limnol Oceanogr 39:1985-1992.

Wentz FJ, Ricciardulli L, Hilburn K, Mears C. 2007. How much more rain will global warming bring? Science 317:233-235.

West GB, Brown JH, Enquist BJ. 1997. A general model for the origin of allometric scaling laws in biology. Science 276:122126.

Wetzel R. 2001. Rivers and lakes - their distribution, origins, and forms. In: Wetzel RG, editor. Limnology (Third Edition). Third Edition. San Diego: Academic Press. pp 15-42. https:// www.sciencedirect.com/science/article/pii/B9780080574394 500071

Whittaker RH. 1962. Classification of natural communities. Bot Rev 28:1-239.

Wilkinson GM, Pace ML, Cole JJ. 2013. Terrestrial dominance of organic matter in north temperate lakes. Global Biogeochemical Cycles 27:43-51.

Williamson TJ, Vanni MJ, Renwick WH. 2020. Spatial and Temporal Variability of Nutrient Dynamics and Ecosystem Metabolism in a Hyper-eutrophic Reservoir Differ Between a 
Wet and Dry Year. Ecosystems. https://doi.org/10.1007/s100 21-020-00505-8.

Wu Q. 2020. 'WhiteboxTools' R Frontend. R package version 1.2.0

Zarnetske JP, Bouda M, Abbott BW, Saiers J, Raymond PA. 2018. Generality of hydrologic transport limitation of watershed organic carbon flux across ecoregions of the United States. Geophys Res Lett 45:11-702.

Zwart JA. 2017. Hydrologic Regulation of Lake Carbon Cycling in Both Time and Space.

Zwart JA, Craig N, Kelly PT, Sebestyen SD, Solomon CT, Weidel BC, Jones SE. 2016. Metabolic and physiochemical responses to a whole-lake experimental increase in dissolved organic carbon in a north-temperate lake. Limnol Oceanogr 61:723734.

Zwart JA, Hanson ZJ, Read JS, Fienen MN, Hamlet AF, Bolster D, Jones SE. 2019. Cross-scale interactions dictate regional lake carbon flux and productivity response to future climate. Geophys Res Lett 46:8840-8851.

Zwart JA, Hanson ZJ, Vanderwall J, Bolster D, Hamlet A, Jones SE. 2018. Spatially explicit, regional-scale simulation of lake carbon fluxes. Global Biogeochemical Cycles 32:1276-1293.

Zwart JA, Sebestyen SD, Solomon CT, Jones SE. 2017. the influence of hydrologic residence time on lake carbon cycling dynamics following extreme precipitation events. Ecosystems 20:1000-1014. 